\title{
Continuous Breeding of Marine Pelagic Copepods in the Presence of Heterotrophic Dinoflagellates
}

\author{
W. C. M. Klein Breteler \\ Netherlands Institute for Sea Research, Postbox 59, Texel, The Netherlands
}

ABSTRACT: A simple technique for cultivation of pelagic copepods through multiple generations is described. Heterotrophic dinoflagellates, cultivated together with Acartia clausi, Temora longicornis and Centropages hamatus, appeared to be very useful as food for the copepods, and controlled the fouling of water and tanks. The generation time of the copepods was about 20 $\mathrm{d}$ at $15^{\circ} \mathrm{C}$, mortality averaged 0.014 to $0.038 \mathrm{~d}^{-1}$. Application of the method in mass cultures and mariculture, and the role of heterotrophy in the pelagic ecosystem are discussed.

\section{INTRODUCTION}

The importance of pelagic copepods in marine ecosystems has led to many attempts to breed marine copepods under controlled conditions in the laboratory for experimental purposes. For review consult 'Marine Ecology', Volume III: Kinne (1977). In the last decade some progress in cultivating pelagic copepods has been made. Laborious routine work or complicated techniques were necessary to maintain copepod populations through 1 or more generations. Usually copepods were bred in water volumes of a few liters or less (Zillioux and Wilson, 1966; Corkett, 1967, 1970; Heinle, 1969, 1970; Katona and Moodie, 1969; Parrish and Carr, 1976; Parrish and Wilson, 1978). Larger volumes of several to $100 \mathrm{l}$ were employed by Mullin and Brooks (1967), Zillioux (1969), Nassogne (1970), Paffenhöfer (1970), and Person-Le Ruyet (1975). Problems mainly arose from the required high concentrations of algal food, leading to heavy sedimentation of algae and algal debris. This necessitated frequent renewing of the culture medium and cleaning of the culture vessels to control bacterial fouling. In the larger culture systems special constructions were used to control water quality (Zillioux, 1969), or to keep the algae in suspension (Paffenhöfer, 1970).

This paper reports the success of a simple technique to maintain and raise breeding stocks of quantitatively important calanoid copepod species of the North Sea, Acartia clausi, Temora longicornis, Centropages hamatus, and of other copepod species, together with heterotrophic dinoflagellates as food and as fouling controlling organisms.

\section{MATERIALS AND METHODS}

One unialgal culture of Isochrysis galbana and 1 or 2 of Rhodomonas sp. were grown at $15^{\circ} \mathrm{C}$ in a chemostat on $\mathrm{f} / 2$-medium (Guillard, 1975). $20 \mathrm{l}$ of this medium were prepared by sterile filtration once per month for each culture. A $16 / 8$ h light/dark cycle was used with 2 cool-white Philips 55 fluorescent tubes of $20 \mathrm{~W}$ on 2 sides of the cultures. The cultures were maintained in Erlenmeyer flasks of $2 \mathrm{l}$ at a dilution rate of $0.26-0.50$ $\mathrm{d}^{-1}$. Compressed air was supplied as carbondioxide source. The concentration of Rhodomonas sp. and $I$. galbana varied from $0.6-1.2$, and $2.0-5.0 \cdot 10^{6}$ cells $\mathrm{ml}^{-1}$, respectively. A sterile technique and a mechanical stirring device proved essential for operating the cultures continuously for a year or longer. When working with Acartia clausi, these conditions were not met; this repeatedly led to loss of algal cultures and, hence, to variable production of algae as food for the copepods.

Copepods were collected in September and October 1977 and 1978 in a basin of $4500 \mathrm{~m}^{3}$ on the island Texel, the Netherlands. The basin is replenished discontinuously with water from the Wadden Sea, and contained dense populations of calanoid copepods, mainly Acartia clausi, but also A. bifilosa, A. tonsa, $A$. discaudata, Centropages hamatus, and Temora longicornis. Collections were made with a hand-towed net (diameter $30 \mathrm{~cm}$, mesh size $100 \mu \mathrm{m}$ ). The copepods caught were sorted immediately in the laboratory, using MS 222 Sandoz as anaesthetic. About 30 individuals of $A$. clausi, $C$. hamatus or $T$. longicornis were brought into $100-\mathrm{l}$ green fiberglass tanks with water 
filtered through a filter of $2 \mu \mathrm{m}$ porosity. After a few weeks, when a new generation had developed, a second selection and cultivation in a new tank was sometimes necessary to obtain monospecific cultures of copepods. Thereafter, each time when reasonably large numbers of newly hatched larvae appeared, half of the tank contents was siphoned to a new tank through a net with $100 \mu \mathrm{m}$ meshes, allowing only eggs and naupliar Stages I and II to pass. Both tanks were filled with filtered sea water. The new tank contained the next breeding stock, the old one was kept as reserve and for experimental purpose. Thus routine maintenance was simple, comprising the renewing of the tank and half of the water at each new generation. Cleaning of the tanks and other material only required a brush and cold fesh water.

Two or three times per week a 1-l sample was taken from the tanks to determine growth and the production of new offspring. The copepods were collected on a nylon sieve with a mesh size of $50 \mu \mathrm{m}$. Counts and measurements were made under a dissecting microscope with an ocular micrometer and a magnification of $40 \mathrm{x}$. The copepods were anaesthesized in about $0.05 \%$ MS 222 and measured alive, since killing them, e. g. in formaldehyde or high concentrations of MS 222, appeared to increase the cephalothorax length of individual Temora nauplii by $3.5 \pm 1.2 \%$ and of copepodids by $6.9 \pm 1.0 \%$ (mean and its $95 \%$ confidence interval) immediately. Superficial observations showed similar increases for Acartia and Centropages. This is in contrast to data of Durbin and Durbin (1978) who found no statistically significant changes in the size of A. clausi after preservation.

All experiments were done in temperature-controlled rooms at $15^{\circ} \mathrm{C}$ with aged sea water from the Wadden Sea, which had a salinity of $32 \% \mathrm{~S}$ in experiments with Acartia and $28 \% \mathrm{~S}$ in experiments with Temora and Centropages. The water was stored in tanks of $60 \mathrm{~m}^{3}$, and, until used, circulated continuously via sand filters (de Blok, 1975). Culture tanks were covered with a plexiglass lid to diminish the risk of accidental contamination from other tanks or water supplies. Mixing and aeration occurred by gently blowing compressed air at the bottom corner of each tank. A 12-h light/dark cycle was applied with $240 \mathrm{~W}$ Philips 55 fluorescent tubes above the cultures. Food was administered daily from Isochrysis and Rhodomonas continuous cultures with a time-regulated peristaltic pump. When working with Acartia difficulties in the continuity of algal cultures led to variable algal supply, making up daily concentrations of 3,200-18,000 cells $\mathrm{ml}^{-1}$ of Isochrysis and 3,000-10,500 cells $\mathrm{ml}^{-1}$ of Rhodomonas in each tank. When working with Temora and Centropages the main problem with the algae cultures was solved, and daily final concentrations of $3,400-8,500$ cells $\mathrm{ml}^{-1}$ of Isochrysis and 2,300-5,300 cells $\mathrm{ml}^{-1}$ of Rhodomonas were supplied.

In addition to the algae administered, various species of heterotrophic dinoflagellates spontaneously populated the copepod cultures. During the first year, when breeding Acartia, no attempt was made to control these flagellates. Later on, in cultures with Temora and Centropages, Oxyrrhis marina was routinely inoculated into the cultures, and other species of dinoflagellates did not recur.

\section{RESULTS}

\section{Algae and Dinoflagellates}

When cultures of copepods are carefully washed with filtered sea water the daily supply with algae and their continuing growth quickly gives rise to high concentrations of about 20,000 and 100,000 cells ml $^{-1}$ of Rhodomonas and Isochrysis, respectively. Such concentrations colour the water densely green and lead to heavy sedimentation of mainly Rhodomonas on the bottom of the tank. However, within a few weeks unarmoured dinoflagellates always inhabited washed cultures, reaching densities of about 2,000 cells $\mathrm{ml}^{-1}$. Of the species regularly observed, Oxyrthis marina (length 17 to $35 \mu \mathrm{m}$ ) was most common and abundant. Three other unidentified Gymnodinium-like species of 8-12, 12-15, and 25-30 $\mu \mathrm{m}$ were present also, however, usually not together with $O$. marina. Most of these naked dinoflagellates feed holozoically, i. e. they eat other organisms (Lebour, 1925; Barker, 1935), although $O$. marina can also satisfy most of its nutritional requirements by osmotrophy (Provasoli, 1977).

Direct evidence that the dinoflagellates eat the algae can easily be obtained by observations under the microscope. Occasionally, algae were seen being caught and swallowed by Oxyrrhis. Moreover, Oxyrrhis cells may be densely packed with still recognizable algal cells, depending on whether they live in filtered sea water or in Isochrysis or Rhodomonas suspensions. At this writing, Oxyrrhis is also kept in continuous culture directly coupled to a Rhodomonas continuous culture. Densities of about 30,000 cells ml $^{-1}$ are reached. This opens up possibilities for experiments with Oxyrhis as single food source for copepods.

In contrast to newly-washed cultures, standard copepod cultures with heterotrophic dinoflagellates never contained high concentrations of algae. In spite of the daily contribution of algae, consumption by the dinoflagellates obviously kept the density of Isochrysis and Rhodomonas at low levels of about 5,000 and 1,000 
cells $\mathrm{ml}^{-1}$, respectively. In this situation the water remains almost transparent, and sedimentation of algal debris on the bottom is negligible.

\section{Copepods}

Table 1 demonstrates the typical development of naupliar and copepodid stages of the 3 copepod species during 1 generation, started at Day 0 with eggs and naupliar Stages I and II. During development most copepods were found in 2 or 3 successive stages, reflecting more or less synchronous growth. After $17 \mathrm{~d}$ new brood appeared, providing new start material for the next culture.

Table 1. Acartia clausi, Temora longicomis and Centropages hamatus. Growth and densities (number $1^{-1}$ ) of 3 copepod species through the various stages

\begin{tabular}{|c|c|c|c|c|c|c|c|c|c|c|c|c|}
\hline \multirow{3}{*}{$\begin{array}{c}\text { Day of } \\
\text { experiment }\end{array}$} & \multicolumn{12}{|c|}{ Densitiy in stage } \\
\hline & \multicolumn{6}{|c|}{ Nauplius } & \multicolumn{6}{|c|}{ Copepodid } \\
\hline & I & II & III I & IV & V & VI & I & II & III & IV & V & VI \\
\hline \multicolumn{13}{|l|}{ Acartia clausi } \\
\hline 3 & & 1 & 10 & 2 & 2 & & & & & & & \\
\hline 6 & & & 1 & & 3 & 2 & & & & & & \\
\hline 9 & & & 1 & & & 1 & & 5 & 4 & & & \\
\hline 13 & & & & & & & & 1 & 1 & 1 & 11 & 3 \\
\hline 15 & & & & & & & & & & & & 11 \\
\hline 17 & 20 & 1 & & & & & & & & & & 1 \\
\hline 20 & & 10 & 5 & & & & & & & & & 8 \\
\hline \multicolumn{13}{|c|}{ Temora longicornis } \\
\hline 1 & 2 & 2 & & & & & & & & & & \\
\hline 3 & & 3 & 5 & 3 & 1 & & & & & & & \\
\hline 6 & & & & & 4 & 5 & 3 & & & & & \\
\hline 10 & & & 1 & & & & 4 & 3 & & & & \\
\hline 15 & & & & & 1 & & & & 1 & 1 & 1 & 1 \\
\hline 17 & 1 & 3 & & & & & & & 1 & 3 & 2 & \\
\hline 20 & 11 & 8 & & & & & & & & 2 & 2 & 5 \\
\hline \multicolumn{13}{|c|}{ Centropages hamatus } \\
\hline 1 & & 15 & 1 & & & & & & & & & \\
\hline 3 & & 11 & 8 & 4 & & & & & & & & \\
\hline 7 & & & & 3 & 8 & 14 & 2 & & & & & \\
\hline 9 & & & & 1 & 1 & 4 & 5 & 7 & 8 & & & \\
\hline 13 & & & & & & & 1 & 1 & 9 & 8 & 6 & \\
\hline 15 & & & & & & & & & 5 & 3 & 9 & 3 \\
\hline 17 & 4 & & & & & & & & & 4 & 6 & 7 \\
\hline 20 & 63 & 19 & & & & & & & & 1 & 2 & 16 \\
\hline
\end{tabular}

Table 2 gives an impression of the present breeding success. In Acartia clausi, 10 successive generations were bred. Unfortunately, the last one was started with a tenfold density of larvae compared with normal densities. These copepods grew well, but depletion of dinoflagellate food led to failure of brood production and to extermination of the culture. Similar failure was experienced with Temora and Centropages cultures when started with too many larvae at the ambient
Table 2. Acartia clausi, Temora longicornis and Centropages hamatus. Breeding success and population characteristics

\begin{tabular}{|lccc|}
\hline Parameter & A. clausi & T. longicornis & C. hamatus \\
\hline $\begin{array}{l}\text { Number of } \\
\text { generations }\end{array}$ & 10 & 13 & 11 \\
$\begin{array}{l}\text { Generation } \\
\text { time }(d .)\end{array}$ & 19.2 & 20.6 & 19.7 \\
$\begin{array}{l}\text { Mortality } \\
\text { rate }\left(d^{-1}\right)\end{array}$ & 0.038 & 0.035 & 0.014 \\
\hline
\end{tabular}
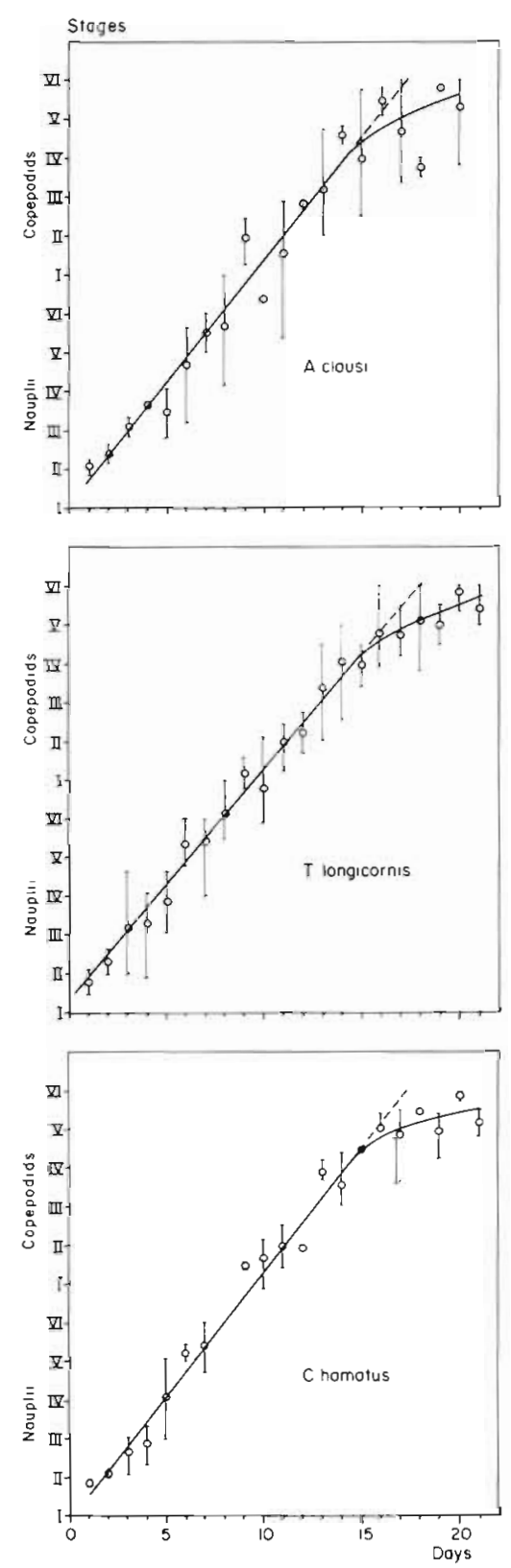

Fig. 1. Acartia clausi, Temora longicornis and Centropages hamatus. Development as a function of time. Combined data from all cultures. Symbols and bars indicate means and ranges, respectively, of average life-cycle stages in different cultures sampled on the same relative date 
feeding level. Therefore, when necessary, our present routine procedure includes dilution of the starting material to 20 nauplii $1^{-1}$ or less. Until now more than 10 generations of Temora and Centropages have been grown, and culturing still proceeds continuously. Under similar conditions also occasional populations of 4 other species, A. bifilosa, A. tonsa, A. discaudata and Eurytemora affinis, were bred without difficulty.

The generation time, defined as the time from the start with larvae till the appearance of about $20 \mathrm{Nau}-$ plius I and II or more $1^{-1}$, was generally between $2 \frac{1}{2}$ and 3 weeks, with an average of about $20 \mathrm{~d}$ for all 3 species (Table 2),

Mortality rates $(Z)$ were calculated from densities ( $N$ ) in samples taken at Day 0 to $t$, according to

$$
N_{t}=N_{o} \cdot e^{-Z t}
$$

Generally $Z$ ranged between zero and $0.040 \mathrm{~d}^{-1}$. Average rates (Table 2 ) correspond to 46 to $75 \%$ survival during 1 generation.

The development of Acartia clausi, Temora longicornis and Centropages hamatus through the various stages is shown for all cultures in Figure 1. Development through the various stages proceeds linearly with time in all 3 species, except for the oldest stages, which is of course due to maturation of the population.

\section{DISCUSSION AND CONCLUSIONS}

This study demonstrates that with simple equipment and rough methods generations of marine copepods can be bred in apparently endless succession. In contrast to the practice of other workers, no antibiotics or sterilization techniques were used. Frequent transfer of copepods, or special devices for a continuous change, circulation, or filtration of water were not necessary either. A fiberglass tank with coarsely filtered sea water and gentle aeration was sufficient to maintain breeding stocks of up to about 40 copepods $1^{-1}$ at the ambient food concentration. The key to this cultivation success appears to be the introduction of holozoic dinoflagellates. These organisms control densities of other algae to low levels, which results in hardly any fouling on walls and bottom, and almost clear water in the culture tanks. Zillioux (1969) successfully introduced a ciliate in his culture system to control algal debris and associated bacterial fouling on the bottom of the tank. Person-Le Ruyet (1975) reported similar effects when harpacticoid copepods occurred together with pelagic copepods.

A second advantage of dinoflagellates may be that these organisms keep themselves well in suspension, and probably are excellent food for pelagic copepods. Preliminary observations on food consumption of Temora longicornis gave direct evidence that Oxyrrhis marina is eaten by copepodids and at least also by the larger nauplii (unpublished observations). Moreover, also in the copepod cultures repeated observations clearly established that the $O$. marina population was completely exterminated at high concentrations of copepods. In spite of the continuous supply with Isochrysis and Rhodomonas lack of $O$. marina led to failure of brood production and extermination of the Acartia clausi culture. Therefore, it seems that in our cultures the copepods cannot thrive on the algae alone. Obviously, $O$. marina constitutes an important food source in the cultures. The precise role of the dinoflagellates and the algae in the food of the various developmental copepod stages is subject to further study.

The importance of heterotrophic flagellates in natural ecosystems was stressed by Sieburth et al. (1978). Heinle et al. (1977) state that protozoans may play an important role as link between detritus and copepods. The significance of this pathway of energy transport to higher trophic levels is substantiated by the suitability of ciliates (Berk et al., 1977) and of heterotrophic flagellates (this study) as food for copepods. Many of these flagellates have delicate cell walls and lyse when one tries to preserve them with conventional methods (Lebour, 1925; Bernard et al., 1967; Reynolds, 1973). In the absence of suitable preservation techniques it may be expected that natural densities of colourless flagellates and, hence, their importance as food for zooplankton, are generally underestimated.

Linear growth through the life stages in the course of time implies that all stages had about the same duration. This growth pattern, called isochronal development by Miller et al. (1977), has already been demonstrated for Acartia tonsa (Heinle, 1966), A. clausi (Landry, 1975), Eurytemora affinis (Miller et al., 1977) and for Pseudocalanus minutus (Corkett and McLaren, 1978). This study adds Temora longicornis and Centropages hamatus to this list. It seems therefore that isochronal growth is a more general phenomenon in marine copepods, as was already assumed by McLaren (1978) in predicting generation lengths of various species.

Generation time has not been assessed very accurately in this study. By sampling only 2 or 3 times per week new brood may have been discovered 1 to $3 \mathrm{~d}$ too late and, hence, generation time may have been overestimated. Nevertheless, the values observed for the 3 copepod species are comparable to the shortest durations derived from other workers at about $15^{\circ} \mathrm{C}$ (Eriksson, 1973; Landry, 1975; Iwasaki et al., 1977; McLaren, 1978). Since excess food seems to be required for isochronal development (Miller et al., 1977), this growth pattern together with the short generation times observed indicate that feeding conditions in the 
present cultivation were excessive during all stages of development.

Our results were obtained in tanks with a volume of 100 l. This volume is somewhat unpractical for laboratory-scale experiments when many parallel cultures are kept under various conditions. On the other hand, the volume is too small for mass cultivation. Preliminary data on breeding in small glassfiber tanks of 25 l give results comparable to those in 100-l tanks. Incidental observations with glassfiber tanks of $1 \mathrm{~m}^{3}$ indicate that the method described here seems easily applicable to mass cultivation of copepods. Therefore, with certain adaptations, the method may be of value in rearing copepods for use in mariculture of higher organisms.

\section{LITERATURE CITED}

Barker, H. A. (1935). The culture and physiology of marine dinoflagellates. Arch. Mikrobiol. 6: 157-181

Berk, S. G., Brownlee, D. C., Heinle, D. R., Kling, H. J., Colwell, R. R. (1977). Ciliates as a food source for marine planktonic copepods. Microb. Ecol. 4: 27-40

Bernhard, M., Rampi, L, Zattera, A. (1967). A phytoplankton component not considered by the Utermöhl method. Pubbl. Staz. zool. Napoli 35: 170-214

Blok, J. W. de (1975). The texel aquarium. Neth. J. Sea Res. 9: 231-242

Corkett, C. J. (1967). Technique for rearing marine calanoid copepods in laboratory conditions. Nature, Lond. 216: $58-59$

Corkett, C. J. (1970). Techniques for breeding and rearing marine calanoid copepods. Helgoländer wiss. Meeresunters. 20: 318-324

Corkett, C. J., McLaren, I. A. (1978). The biology of Pseudocalanus. Adv mar. Biol. 15: 2-231

Durbin, E. G., Durbin, A. G. (1978). Length and weight relationships of Acartia clausi from Narragansett Bay, R. I. Limnol. Oceanogr. 23: 958-969

Eriksson, S. (1973). The biology of marine planktonic copepods on the west coast of Sweden. Zoon 1: 37-68

Guillard, R. R. L. (1975). Culture of phytoplankton for feeding marine invertebrates. In: Smith, W L., Chanley, M. H. (eds) Culture of marine invertebrate animals. Plenum Press, New York, pp. 29-60

Heinle, D. R. (1966). Production of a calanoid copepod, Acartia tonsa, in the patuxent River estuary. Chesapeake Sci. 7: 59-74

Heinle, D. R. (1969). Culture of calanoid copepods in synthetic sea water. J. Fish. Res. Bd Can. 26: 150-153

Heinle, D. R. (1970). Population dynamics of exploited cultures of calanoid copepods. Helgoländer wiss. Meeresunters. 20: $360-372$
Heinle, D. R, Harris, R. P., Ustach, J. F., Flemer, D. A. (1977). Detritus as food for estuarine copepods. Mar Biol. 40: 341-353

Iwasaki, H., Katoh, H., Fujiyama, T (1977). Cultivation of the marine copepod, Acartia clausi Giesbrecht: I. Factors affecting the generation time and egg production. Bull. Plankton Soc. Japan 24: 55-61

Katona, S. K. Moodie, C. R. (1969). Breeding of Pseudocalanus elongatus in the laboratory. J. mar biol. Ass. U. K. 49 : 743-747

Kinne, O. (1977). Cultivation of animals: research cultivation. In: Kinne, O. (ed.) Marine ecology, Vol. III, Cultivation, Part 2. Wiley, London, pp. 579-1293

Landry, M. R. (1975). The relationship between temperature and the development of life stages of the marine copepod Acartia clausi Giesbr. Limnol. Oceanogr. 20: 854-858

Lebour, M. V. (1925). The dinoflagellates of Northern Seas, Marine biological Association, United Kingdom

McLaren, I. A. (1978). Generation lengths of some temperate marine copepods: estimation, prediction, and implications. J. Fish. Res. Bd Can. 35: 1330-1342

Miller, C. B., Johnson, J. K., Heinle, D. R. (1977). Growth rules in the marine copepod genus Acartia. Limnol. Oceanogr. 22: $326-335$

Mullin, M. M., Brooks, E. R. (1967). Laboratory culture, growth rate, and feeding behaviour of a planktonic marine copepod. Limnol. Oceanogr 12: 657-666

Nassogne, A. (1970). Influence of food organisms on the development and culture of pelagic copepods. Helgoländer wiss. Meeresunters. 20: 333-345

Paffenhöfer, G.-A. (1970). Cultivation of Calanus helgolandicus under controlled conditions. Helgoländer wiss. Meeresunters. 20: 346-359

Parrish, K. K., Carr, R. A. (1976). Transport of mercury through a laboratory two-level marine food chain. Mar. Pollut. Bull., N. S. 7: 90-91

Parrish, K. K., Wilson, D. F. (1978). Fecundity studies on Acartia tonsa (Copepoda: Calanoida) in standardized culture. Mar. Biol. 46: 65-81

Person-Le Ruyet, J. (1975). Elevage de copépodes Calanoides. Biologie et dynamique des populations: premiers résultats. Annls Inst. océanogr., Monaco 51: 203-221

Provasoli, L. (1977). Axenic cultivation. In: Kinne, O. (ed.) Marine ecology, Vol. III, Cultivation, Part 3. Wiley, Chichester, pp. 1295-1319

Reynolds, N. (1973). The estimation of the abundance of ultraplankton. Br. phycol. J. 8: 135-146

Sieburth, J. McN., Smetacek, V., Lenz, J. (1978). Pelagic ecosystem structure: Heterotrophic compartments of the plankton and their relationship to plankton size fractions. Limnol Oceanogr. 23: 1256-1263

Zillioux, E. J. (1969). A continuous recirculating culture system for planktonic copepods. Mar. Biol. 4: 215-218

Zillioux, E. J., Wilson, D. F. (1966). Culture of a planktonic calanoid copepod through multiple generations. Science, N. Y. 151: $996-998$ 